\title{
Role of FSH and epidermal growth factor (EGF) in the initiation of steroidogenesis in granulosa cells associated with follicular selection in chicken ovaries
}

\author{
A. G. Hernandez* and J. M. Bahr ${ }^{\dagger}$ \\ Department of Animal Sciences, University of Illinois at Urbana-Champaign, Urbana, IL 61801, USA
}

In chicken ovaries, one small yellow follicle (SYF) is selected daily from a pool of follicles of similar size and becomes a preovulatory follicle. FSH induces follicular growth and steroidogenesis. Epidermal growth factor (EGF), an intraovarian hormone, suppresses granulosa cell differentiation. This study demonstrates that recruitment of SYFs into the hierarchy of preovulatory follicles is associated with a change in steroidogenic activity in granulosa cells regulated, at least in part, by FSH and EGF. Abundance of P450 side-chain cleavage (P450scc) mRNA was higher in the smallest preovulatory follicle (F6) compared with SYF, whereas FSH and EGF receptor (FSHr and EGFr, respectively) mRNA abundance was similar. FSH increased P450scc mRNA abundance and progesterone secretion and decreased FSHr mRNA in cultured granulosa cells, whereas EGF attenuated or suppressed P450scc mRNA and decreased FSHr mRNA abundance. None of the hormones influenced EGFr mRNA abundance. When used in combination, EGF attenuated or suppressed the stimulatory effect of FSH on the expression of P450scc mRNA and production of progesterone in a dose-dependent manner. The results indicate that (1) selection is associated with an increase in P450scc mRNA; (2) FSH stimulates expression of P450scc mRNA and progesterone secretion in granulosa cells of SYF; and (3) induction of $\mathrm{P450scc} m R \mathrm{RNA}$ and progesterone secretion by FSH is attenuated or blocked by EGF.

\section{Introduction}

Thousands of follicles are present in chicken ovaries at hatching. However, only a few hundred oocytes will be selected for ovulation during adult life. The precise mechanisms underlying selection of a specific follicle for ovulation are not known. Chicken ovaries are an excellent model to study follicular selection because the stage of follicular development can easily be determined by the size of the follicle. Chicken ovaries contain thousands of cortical follicles (less than $1 \mathrm{~mm}$ in diameter), hundreds of white follicles $(1-5 \mathrm{~mm}$ in diameter), five or six small yellow follicles (SYF; $5-8 \mathrm{~mm}$ in diameter) and five or six preovulatory follicles (10$35 \mathrm{~mm}$ in diameter), arranged in a hierarchy. A single follicle is selected each day from the pool of SYF to join the exclusive group of preovulatory follicles destined for ovulation.

Gonadotrophins are the primary regulators of follicular growth and ovulation. $\mathrm{FSH}$ is responsible for follicular

\footnotetext{
*Present address: Biotechnology Center, W. M. Keck Center for Comparative and Functional Genomics, University of Illinois at Urbana-Champaign, 1201 W. Gregory Drive, Urbana, IL 61801, USA

${ }^{\dagger}$ Correspondence

Email: jbahr@uiuc.edu
}

recruitment and growth of the smaller follicles. Daily injections of FSH increase the number of white follicles, SYF and preovulatory follicles without disrupting the hierarchy in mature hens (Palmer and Bahr, 1992). The granulosa layer of SYF and the sixth (F6) to the third (F3) largest follicles are the primary targets for $\mathrm{FSH}$, on the basis of measurement of FSH receptors (FSHr), FSHr mRNA and FSH-stimulated adenylyl cyclase activity (Calvo et al., 1981; Calvo and Bahr, 1983; Bahr and Calvo, 1984; Ritzhaupt and Bahr, 1987; You et al., 1996; Zhang et al., 1997). FSH stimulates progesterone production in granulosa cells from F6-F3 follicles (Hammond et al., 1981). Plasma concentrations of $\mathrm{FSH}$ are relatively constant during the ovulatory cycle, with the exception of a small but significant increase $12 \mathrm{~h}$ before ovulation (Krishnan et al., 1993). The primary target for $\mathrm{LH}$ is the granulosa layer of the larger preovulatory follicles (Calvo et al., 1981; Calvo and Bahr, 1983; Bahr and Calvo, 1984). LH promotes progesterone secretion by the granulosa cells of primarily F3 to the largest (F1) follicles (Hammond et al., 1981).

The actions of gonadotrophins in ovaries are modulated by intraovarian growth factors. Among the various growth factors identified in chicken ovaries, epidermal growth factor (EGF) and transforming growth factor $\alpha$ have been studied most extensively. The oocyte (germinal disc) and granulosa cells in preovulatory 
follicles synthesize EGF (Volentine et al., 1998; Yao and Bahr, 2001a). Immunostaining for EGF is also detected in granulosa layers of small unselected follicles (Onagbesan et al., 1994). Both granulosa and theca layers of unselected and preovulatory follicles express EGF receptor (EGFr) and are target tissues for EGF, on the basis of the presence of EGFr protein (Onagbesan et al., 1994; Yao and Bahr, 2001b). Moreover, EGF acts as a proliferation-promoting and differentiation-inhibiting factor by stimulating DNA synthesis and decreasing progesterone production by cultured granulosa cells (Li and Johnson, 1993; Peddie et al., 1993; Volentine et al., 1998). EGF is known to attenuate stimulatory effects of gonadotrophins on granulosa cell differentiation (Knecht and Catt, 1983; Li and Johnson, 1993).

Granulosa cells of SYF are steroidogenically inactive, owing to low P450 side-chain cleavage (P450scc), the enzyme that converts cholesterol to pregnenolone and other steroidogenic enzymes (Nitta et al., 1991; Tilly et al., 1991). Expression of P450scc and production of progesterone by granulosa cells are observed in preovulatory follicles and thus, can be considered markers of follicular selection. The hormonal milieu that enables a SYF to become a preovulatory follicle has not been identified. It is possible that selection of this follicle is the result of a change in responsiveness to EGF or FSH.

In the first part of this study, denoted here as in vivo experiments, the abundance of FSHr, EGFr and P450scc mRNA of the follicular stages immediately before and after selection (SYF and F6 follicle, respectively) was determined. In the second part of this study (in vitro experiments), granulosa cells from SYF were exposed to $\mathrm{FSH}$ and EGF individually or in combination to determine whether FSH or EGF induces changes in the abundance of mRNA for FSHr, EGFr and P450scc, and progesterone production by these cells. Testing the effects of FSH and EGF individually and in combination allows identification of the role of each hormone in maintaining follicles in a proliferative state (inhibit progesterone secretion) or promoting differentiation (induce progesterone secretion). The overall hypothesis was that FSH promotes selection of SYF into the hierarchy by initiating progesterone production in the granulosa layer of SYF but that EGF can attenuate this induction of steroidogenesis by $\mathrm{FSH}$.

\section{Materials and Methods}

\section{Animals}

Single-comb white Leghorn hens, 20-50 weeks of age, with regular laying sequences of at least six eggs were used for experimentation. Hens were maintained in individual cages, provided with feed and water ad libitum and exposed to a photoperiod of $17 \mathrm{~h}$ light: $7 \mathrm{~h}$ dark, with lights on at 05:00 $\mathrm{h}$ and lights off at 22:00 h. Oviposition was monitored daily at $1 \mathrm{~h}$ intervals between
08:00 and 12:00 h. Animal management and procedures were reviewed and approved by the Division of Animal Research of the University of Illinois at UrbanaChampaign.

\section{Reagents}

The following reagents, obtained from Sigma (St Louis, $\mathrm{MO})$, were used in the cell cultures: collagenase IV Dulbecco's modified Eagle's medium (DMEM), Hepes, $100 \mathrm{U}$ penicillin $\mathrm{ml}^{-1}, 100 \mu \mathrm{g}$ streptomycin $\mathrm{ml}^{-1}, \mathrm{BSA}$, insulin, transferrin, sodium selenite, Hank's buffer salt solution (HBSS), human recombinant epidermal growth factor (rhEGF). Porcine FSH (AFP-10640B; with less than $1.5 \%$ contamination with porcine $\mathrm{LH}$ ) was generously provided by A. F. Parlow. Culture plates were tissuetreated 24-well Costar plates (Corning Inc., Corning, NY). Cell proliferation was determined with CellTiter ${ }^{\circledR} 96$ aqueous one solution cell proliferation assay (Promega, Madison, WI). Reagents used for real-time PCR were purchased from PE Applied Biosystems (Foster City, CA): TaqMan universal PCR master mix, sequence detection primers, TaqMan probes, MicroAmp optical 96-well reaction plates, MicroAmp optical caps and SYBR ${ }^{\circledR}$ green core reagents. Real-time PCR was performed at the W. M. Keck Center for Functional Genomics, University of Illinois at Urbana-Champaign.

\section{Tissue collection}

Chickens were killed by cervical dislocation at $12 \mathrm{~h}$ before the expected time of ovulation, the time at which plasma concentrations of FSH are the highest (Krishnan et al., 1993). Several healthy SYF follicles and the smallest hierarchical follicle (F6) were removed immediately and placed in sterile ice-cold HBSS. Granulosa and theca layers were separated as described by Gilbert et al. (1977). The granulosa layers were immediately frozen at $-70^{\circ} \mathrm{C}$ and stored until further processing.

\section{Cell cultures}

Granulosa cells were cultured as described by Hernandez and Bahr (2002). Briefly, granulosa layers were isolated from SYF and dispersed with type IV collagenase $\left(1.5 \mathrm{mg} \mathrm{m}^{-1}\right)$ in DMEM for $15 \mathrm{~min}$ in a $37^{\circ} \mathrm{C}$ water bath. Cells were washed three times in $1 \mathrm{ml}$ sterile HBSS and resuspended in $1 \mathrm{ml}$ culture medium. Culture medium consisted of DMEM supplemented with 25 mmol Hepes $\mathrm{I}^{-1}$, 3.7 g sodium bicarbonate $\mathrm{I}^{-1}$, $2 \mathrm{~g} \mathrm{BSA} \mathrm{I}^{-1}, 100 \mathrm{U}$ penicillin $\mathrm{ml}^{-1}, 100 \mathrm{mg}$ streptomycin $\mathrm{ml}^{-1}, 5 \mu \mathrm{g}$ insulin $\mathrm{ml}^{-1}, 5 \mathrm{ng}$ sodium selenite $\mathrm{ml}^{-1}$ and $5 \mu \mathrm{g}$ transferrin $\mathrm{ml}^{-1}$. Total cell counts and the number of viable cells were determined by the Trypan 
blue exclusion method using a haemocytometer. Cell viability before culture was consistently higher than $90 \%$. Culture medium was added to the dispersed cells to obtain a final concentration of $1 \times 10^{6}$ per $500 \mu \mathrm{l}$. Cells were cultured in 24-well plates in an incubator with $5 \%$ $\mathrm{CO}_{2}: 95 \% \mathrm{O}_{2}$ at $39^{\circ} \mathrm{C}$ for $18 \mathrm{~h}$.

\section{Experiments}

Experiment 1 (in vivo): abundance of FSHr, EGFr and P450scc mRNA in SYF and F6. Pooled granulosa cells from several SYF and the F6, removed from chickens $12 \mathrm{~h}$ before the expected time of ovulation, were lysed for $15 \mathrm{~s}$ in a microcentrifuge tube with $350 \mu$ l buffer RLT from the Rneasy kit (Qiagen, Valencia, CA). Lysate was snap-frozen and stored at $-80^{\circ} \mathrm{C}$ until further processing.

Experiment 2 (in vitro): effects of different doses of FSH and EGF on abundance of FSHr, EGFr and P450sCC $m R N A$ and progesterone production. Granulosa cells from SYF were cultured as described above and treated with pFSH $\left(0,4,20,50,100\right.$ and $\left.250 \mathrm{ng} \mathrm{ml}^{-1}\right)$, or rhEGF $\left(0,4,10,20,50\right.$ and $\left.100 \mathrm{ng} \mathrm{ml}^{-1}\right)$ for $18 \mathrm{~h}$. Proliferation of granulosa cells was determined by adding $100 \mu \mathrm{l}$ CellTiter $^{\circledR} 96$ at $17 \mathrm{~h}$ of culture for $1 \mathrm{~h}$. Absorbance at $490 \mathrm{~nm}$ was then determined in $300 \mu \mathrm{l}$ culture medium. Background absorbance was determined in a well with culture medium and CellTiter ${ }^{\circledR} 96$ but no cells, and this value was subtracted from all other values. At the end of incubation, culture medium was aspirated and stored at $-20^{\circ} \mathrm{C}$ until processed for measurement of progesterone. Cells were then lysed for $15 \mathrm{~s}$ in the culture wells with $350 \mu$ l buffer RLT. Lysate was aspirated, snap-frozen and stored at $-80^{\circ} \mathrm{C}$ until further processing.

Effects of the combinations of FSH and EGF on abundance of FSHr, EGFr, P450scc mRNA and progesterone production

On the basis of the results of testing FSH and EGF individually (Expt 2; first part), the lowest dose of FSH $\left(4 \mathrm{ng} \mathrm{m}^{-1}\right)$ that produced maximal stimulation of P450scc mRNA, the lowest dose of EGF $\left(4 \mathrm{ng} \mathrm{ml}^{-1}\right)$ that decreased the abundance of P450scc mRNA, and the highest dose of EGF that further decreased P450scC mRNA were chosen to test the combined effect of FSH and EGF on the induction of P450scc mRNA. The reason for using two doses of EGF in these experiments was to test the hypothesis that the amount of EGF to which granulosa cells of SYF are exposed will determine their responsiveness to $\mathrm{FSH}$. Granulosa cells from SYF were exposed to either culture medium alone (control), 4 ng pFSH ml ${ }^{-1}$, 4 or $100 \mathrm{ng} \mathrm{EGF} \mathrm{ml}{ }^{-1}$, or combinations of
FSH and EGF at these same doses for $18 \mathrm{~h}$, and processed as described above. Granulosa cell proliferation was determined as described above.

\section{RNA isolation and reverse transcription}

Total RNA was isolated from the cell lysate using the Rneasy kit (Qiagen) according to the manufacturer's instructions. The RNA was quantified using a spectrophotometer and stored at $-80^{\circ} \mathrm{C}$ until used. Single-stranded complementary DNA (cDNA) was generated from $2 \mu \mathrm{g}$ total RNA with RETROscript ${ }^{\mathrm{TM}}$ first-strand synthesis kit (Ambion Inc., Austin, TX) following the manufacturer's instructions. The cDNA was frozen at $-80^{\circ} \mathrm{C}$ until used for PCR.

\section{Primers and TaqMan probes}

Chicken FSHr, EGFr and P450scc primer sets and probes were designed according to the cDNA sequences from GenBank and published data (Lax et al., 1988; Porunelloor et al., 1990; Johnson et al., 1996; You et al., 1996). The selection of primer sets was based on their minimal secondary structure potential and minimal inter-primer complementarity. Real-time PCR was used for the in vivo experiments. The primers and TaqMan probes were designed with the assistance of the Primer Express software (Table 1). The TaqMan probes were used for detection of FSHr, EGFr and 18S (normalizing control) products. These probes, labelled at the 5'terminal nucleotide with a fluorescent reporter dye, FAM (6-carboxyfluorescein), hybridize specifically to the target PCR product. The sequence detector measures the fluorescent spectra continuously during PCR amplification. The in vitro experiments were performed using semi-quantitative PCR. Primers were generated using the oligonucleotide primer design program, Oligo 4.0 (National Biosciences Inc., Plymouth, MN). Cyclophilin cDNA was monitored separately in each sample by PCR reaction using a mouse cyclophilin primer set (Ambion, Austin, TX) for normalization of the amount of cDNA used for amplification in semi-quantitative PCR.

\section{Real-time PCR}

Abundance of FSHr, EGFr, P450scc and $18 \mathrm{~S}$ (internal control) mRNA was quantified by real-time PCR. Amplification reactions for FSHr, EGFr and $18 \mathrm{~S}(25 \mu \mathrm{l})$ contained $12.5 \mu \mathrm{l}$ TaqMan universal PCR master mix, $1.5 \mu \mathrm{l}$ cDNA template, 10 pmol each primer $(1 \mu \mathrm{l}$ each), 5 pmol probe $(0.3 \mu \mathrm{l})$ and $8.7 \mu \mathrm{l}$ RNase-free water.

Real-time detection of P450scc mRNA products was monitored by using specific primers and SYBR green (instead of a TaqMan probe), a dye that binds to doublestranded DNA during PCR amplification. Reactions $(25 \mu \mathrm{l})$ were carried out with the use of SYBR green core reagents following the manufacturer's protocol, with 
Table 1. Sequence of primers and TaqMan probes used for real-time and semi-quantitative PCR of chicken FSH receptor (FSHr), epidermal growth factor receptor (EGFr) and P450 side-chain cleavage (P450scc) mRNA

\begin{tabular}{|c|c|c|c|c|}
\hline Transcript & Primer & Sequence $\left(5^{\prime} \rightarrow 3^{\prime}\right)$ & Nucleotides & PCR product (bp) \\
\hline \multicolumn{5}{|c|}{ Real-time PCR } \\
\hline \multirow[t]{3}{*}{$\mathrm{FSHr}$} & Forward & CCGGGACATTCCCACCA & $146-215$ & 70 \\
\hline & Reverse & TCССTTCGGAATGACTCTCATC & & \\
\hline & Probe & TGCCACAGAACTGAGATTTGTCСТCACCA & & \\
\hline \multirow[t]{3}{*}{ EGFr } & Forward & CTGGTTGTGGTTGG & $2287-2349$ & 63 \\
\hline & Reverse & GCGCTTCCGCACGATATG & & \\
\hline & Probe & TCGGTCTTTACCTGCGGCGACG & & \\
\hline \multirow[t]{3}{*}{$18 \mathrm{~S}$} & Forward & GATCCATTGGAGGGCAAGTCT & $5-83$ & 79 \\
\hline & Reverse & AACTGCAGCAACTTTAATATACGCTATT & & \\
\hline & Probe & TGCCAGCAGCCGCGGTAATTC & & \\
\hline \multirow[t]{2}{*}{ P450scc } & Forward & ATGCTGAAGAGCATCCGACT & $445-769$ & 325 \\
\hline & Reverse & GGATGTGGATGAGGAAGAGC & & \\
\hline \multicolumn{5}{|c|}{ Semi-quantitative PCR } \\
\hline \multirow[t]{2}{*}{$\mathrm{FSHr}$} & Forward & TGGCCATTACССТАCTGCAT & $50-433$ & 384 \\
\hline & Reverse & TCGTTCTCATAAGCGTCTTCC & & \\
\hline \multirow[t]{2}{*}{ EGFr } & Forward & GACGCACACCATGGGTGTAC & $282-532$ & 251 \\
\hline & Reverse & CGCGATTATGCTCCACGTAG & & \\
\hline \multirow[t]{2}{*}{ P450scc } & Forward & ATGCTGAAGAGCATCCGACT & $445-769$ & 325 \\
\hline & Reverse & GGATGTGGATGAGGAAGAGC & & \\
\hline
\end{tabular}

10 pmol each primer ( $1 \mu \mathrm{l}$ each) and $1.5 \mu \mathrm{l}$ cDNA template.

Real-time PCR was validated (that is, concentration of primers and probes and amplification efficiency of each transcript) and performed as recommended by the manufacturer. For each gene, a no-template control in which cDNA was substituted with water was used to confirm the specificity of the signal. Transcript abundance was normalized for differences in the amount of total RNA added to each reaction by using $18 \mathrm{~S}$ as described by the manufacturer. Briefly, amplification plots from the fluorescent emission during the exponential phase of amplification reaction were constructed with the use of Sequence Detector V1.6.3 software. The threshold cycle $(C t$; number of cycles at which the fluorescence exceeds a threshold limit, which is usually ten times the standard deviation of the baseline fluorescence) was calculated for each sample in the linear portion of the amplification curve. Relative quantitation of transcript abundance, expressed as $\Delta C t$, was performed by subtraction of $C t$ value of the $18 \mathrm{~S}$ from that of the transcript amplified in each reaction.

\section{Semi-quantitative PCR}

PCR was performed using reagents from TaqBead ${ }^{\mathrm{TM}}$ hot start polymerase (Promega, Madison, WI) in a $500 \mu \mathrm{l}$ thin-walled PCR tube. The RT reaction product $(2 \mu \mathrm{l}), 5 \mu \mathrm{l} 10 \times$ magnesium-free reaction buffer, $3 \mu \mathrm{l}$ $\mathrm{MgCl}_{2}\left(25 \mathrm{mmol} \mathrm{I^{-1 }}\right), 8 \mu \mathrm{l}$ dNTP $\operatorname{mix}\left(200 \mu \mathrm{mol} \mathrm{I} \mathrm{I}^{-1}\right.$ each dNTP), $0.5 \mu \mathrm{l}$ sense and $0.5 \mu \mathrm{l}$ antisense primers
( $1 \mu \mathrm{mol} \mathrm{I} \mathrm{I}^{-1}$ each) were combined and brought to a volume of $50 \mu \mathrm{l}$ with nuclease-free water. TaqBead hot start polymerase was added and the reaction was covered with $30 \mu \mathrm{l}$ mineral oil. The amplification of the RT product followed the general PCR protocol using a RTC-100TM thermocycler (MJ Research Inc., Watertown, MA). The reaction was first heated to $94^{\circ} \mathrm{C}$ for $4 \mathrm{~min}$ and then subjected to 26 cycles of a pre-set programme $\left(94^{\circ} \mathrm{C}\right.$ for $2 \mathrm{~min}, 55^{\circ} \mathrm{C}$ for $1.5 \mathrm{~min}$, and $72^{\circ} \mathrm{C}$ for $1.5 \mathrm{~min}$ ) for $\mathrm{FSHr}$ and $\mathrm{P} 450 \mathrm{scc}$, 24 cycles for cyclophilin and 32 cycles for EGFr. The reaction was then extended for $5 \mathrm{~min}$ at $72^{\circ} \mathrm{C}$ and paused at $4{ }^{\circ} \mathrm{C}$. PCR product $(15 \mu \mathrm{l})$ was routinely run on a $1.5 \%$ agarose gel with ethidium bromide at 100 volts for $1.5 \mathrm{~h}$ for size analysis.

\section{Quantification of semi-quantitative PCR products}

The gel image was captured with CCD camera imaging system (FOTO/Analyst image analysis system; Fotodyne Inc., Hartland, WI). Band densities were then analysed densitometrically with Collage ${ }^{\mathrm{TM}}$ image analysis software (Fotodyne). The band density of cyclophilin cDNA was used to determine the relative abundance of FSHr, EGFr and P450scc expression in each sample. The ratio of band density of cyclophilin cDNA to the FSHr, EGFr and P450scc cDNA was calculated.

\section{Radioimmunoassay}

Concentrations of progesterone in culture media were determined by radioimmunoassay (Bahr et al., 1983). 
The sensitivity of the assay was $5.37 \mathrm{pg}$ per tube. The interassay and intra-assay coefficients of variation were 3.2 and $3.1 \%$, respectively.

\section{Experimental design and statistical analysis}

Pooled granulosa cells from SYF and the granulosa cells from the F6 were analysed with chicken as the experimental unit for the in vivo experiments. The experiments were repeated three times ( $n=3$ chickens). Granulosa cells from SYF from two chickens were pooled for each experiment for the in vitro experiments. Two wells were cultured with $1 \times 10^{6}$ cells each for each dose of hormone or combinations of hormones to obtain sufficient total RNA for subsequent measurements. Each experiment was replicated at least four times $(n=4)$. The band density of cDNA was measured twice and the results were averaged. The abundance of each transcript was calculated as the density of the target transcript relative to the density of cyclophilin for that sample. The abundance of each transcript is presented as relative to the dose 0 (control), with dose $0=1$. Production of progesterone was calculated relative to the cell proliferation index for each hormone and dose. Data were assigned rank values using the PROC RANK command in the Statistical Analysis Program (SAS). ANOVA was used to test the main effects of follicle (in vivo) or each hormone or combinations of these hormones (in vitro). Chicken (in vivo) or culture replicate (in vitro) were included in the model as an error term. Differences between follicles or doses of hormones were identified by orthogonal contrasts. Differences were considered significant when $P<$ 0.05 .

\section{Results}

Experiment 1: FSHr, EGFr and P450scc mRNA abundance in SYF and F6 follicles (in vivo experiment)

Abundance of FSHr, EGFr and P450scc mRNA was compared between SYF and F6 follicles $12 \mathrm{~h}$ before ovulation (Fig. 1). The abundance of FSHr and EGFr mRNA in F6 follicles $(\Delta C t=-5.34 \pm 0.29$ and $-4.51 \pm 0.15$, respectively) was not different from that measured in SYF. However, the abundance of P450scc mRNA in F6 follicles $(\Delta C t=-5.80 \pm 0.67)$ was significantly higher than in SYF $(\Delta C t=-9.17 \pm 0.37 ; P<0.01)$.

\section{Experiment 2: dose effects of FSH and EGF on} abundance of FSHr, EGFr and P450scC MRNA and progesterone production (in vitro experiment)

The abundance of cyclophilin mRNA was not affected by any dose of FSH, EGF or their combinations (results not shown).

FSH in doses of 4, 20, 100 and $250 \mathrm{ng} \mathrm{ml}^{-1}$ significantly decreased the abundance of FSHr mRNA $(P \leqslant 0.02$; Fig. 2a) in relation to the control. The abundance of
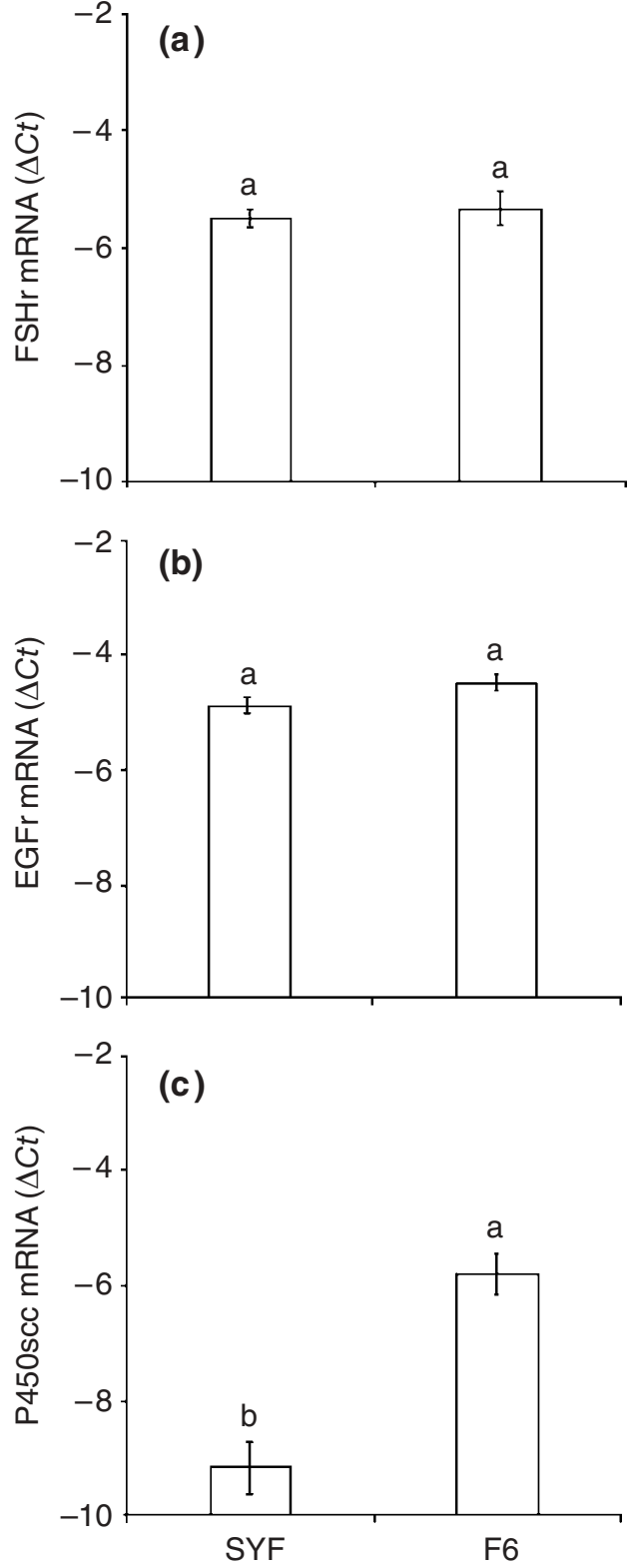

Fig. 1. Abundance of (a) FSH receptor (FSHr), (b) epidermal growth factor receptor (EGFr) and (c) P450 side-chain cleavage (P450scc) mRNA in granulosa cells of small yellow follicles (SYF) and F6 follicles (stages before and after selection, respectively) in chicken ovaries. Total RNA was extracted from granulosa cells of SYF or F6 and transcript abundance was determined by real-time PCR. Relative quantitation of transcript abundance, expressed as $\Delta C t$, is performed by subtraction of $C t$ (threshold cycle) value of the $18 \mathrm{~S}$ (normalizing control) from that of the transcript amplified in each reaction. Different subscripts indicate significant differences $(P<$ 0.05).

EGFr mRNA was not affected by any dose of FSH. FSH had a significant positive impact on P450scc mRNA and progesterone production, which were increased at all doses $(P<0.001)$. 

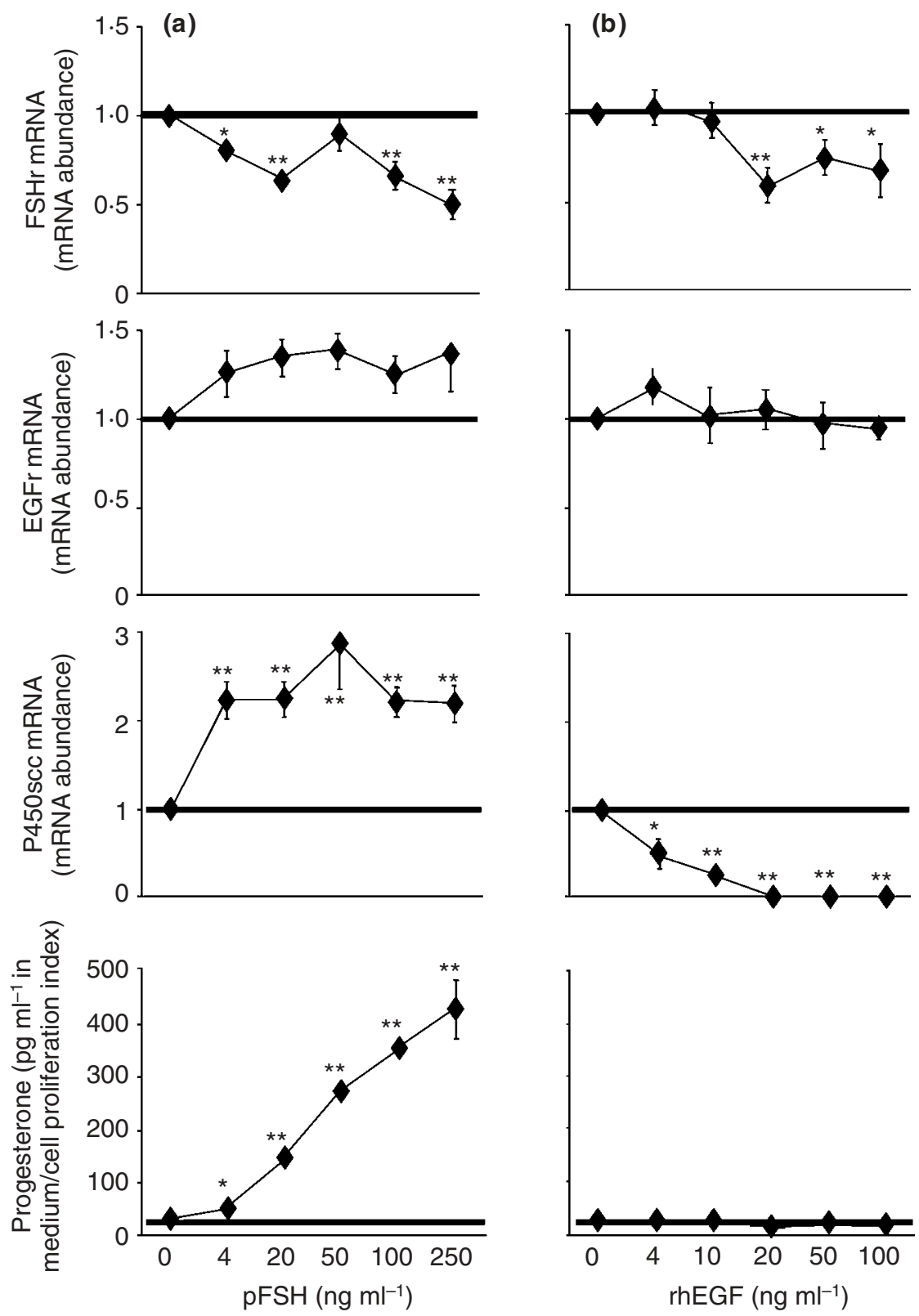

Fig. 2. Abundance of FSH receptor (FSHr), epidermal growth factor receptor (EGFr) and $\mathrm{P} 450$ side-chain cleavage (P450scc) mRNA in and production of progesterone by granulosa cells of small yellow follicles (SYF) in response to (a) pig FSH (pFSH) and (b) human recombinant epidermal growth factor (rhEGF) in chicken ovaries. Granulosa cells from SYF were cultured for $18 \mathrm{~h}$ with different doses of the hormones. Transcript abundance was determined by semi-quantitative PCR. Data for FSHr, EGFr and P450scC mRNA are expressed as mean \pm SEM $(n=5)$, relative to dose $0 \mathrm{ng} \mathrm{ml}^{-1}$, with dose $0=1$. Data for progesterone production are expressed as mean $\pm \operatorname{SEM}(n=5) \mathrm{pg} \mathrm{ml}^{-1}$ in culture medium relative to cell proliferation index. Significant differences from dose 0 are denoted as $* P<0.05$ or $* * P<0.01$.

EGF decreased the abundance of FSHr mRNA at doses of 20, 50 and $100 \mathrm{ng} \mathrm{ml}^{-1}(P<0.05$; Fig. 2b). There was no significant effect of EGF on the relative abundance of EGFr mRNA. P450scc mRNA abun- dance was decreased by all doses of EGF $(P<$ 0.01), with undetectable measurement at $20 \mathrm{ng}$ EGF $\mathrm{ml}^{-1}$. Progesterone production remained unchanged compared with the control. 
Effect of combinations of FSH and EGF on abundance of FSHr, EGFr and P450sCC mRNA in SYF and progesterone production by SYF

None of the combinations of hormones influenced the abundance of EGFr mRNA in SYF and, consequently, the results are not shown.

When granulosa cells from SYF were exposed to $4 \mathrm{ng}$ FSH ml-1 and EGF at a low dose $\left(4 \mathrm{ng} \mathrm{ml}^{-1}\right)$ or a high dose $\left(100 \mathrm{ng} \mathrm{m}^{-1}\right)$, the abundance of $\mathrm{FSHr}$ mRNA was lower than the control abundance $(P<$ 0.01 ), but not different from that of FSH alone (Fig. 3). The low dose of EGF neutralized the stimulatory effect of FSH on P450scc mRNA and the high dose of EGF reduced P450scc mRNA abundance below unstimulated values, indicating the ability of EGF to actively suppress P450scc mRNA synthesis (Fig. 3). The low dose of EGF partially neutralized the stimulatory effects of $\mathrm{FSH}$ on progesterone production and the high dose of EGF completely eliminated the effect of FSH. Progesterone production by cells treated with the high dose of EGF and FSH did not differ from that of untreated cells.

\section{Discussion}

The aim of the present study was to understand the role of FSH and EGF in the selection of a SYF to enter the hierarchy of preovulatory follicles in chickens. The novel finding is that the marked difference between SYF (unselected follicles) and F6 (smallest selected follicles) is a twofold increase in P450scc mRNA abundance, which occurred in the absence of changes in $\mathrm{FSHr}$ or EGFr mRNA abundance. The in vitro experiments showed that $\mathrm{FSH}$ is a positive driving factor for inducing steroidogenesis in granulosa cells of SYF, by increasing P450scc mRNA and progesterone secretion. In contrast, EGF is a potent suppressor of the robust steroidogenic response of granulosa cells to $\mathrm{FSH}$.

The significant increase in P450scc mRNA abundance in the F6 follicle (the most recent selected follicle), compared with SYF (immediate stage before selection) indicates that follicular selection is directly associated with the onset of steroidogenic activity in granulosa cells. After a SYF is selected and becomes a preovulatory follicle, the abundance of FSHr mRNA, FSHr binding and the responsiveness of the adenylyl cyclase system to FSH in granulosa cells decreases (Bahr and Calvo, 1984; You et al., 1996; Zhang et al., 1997). At the same time, progesterone production increases progressively (Bahr et al., 1983; Palmer and Bahr, 1992). These physiological changes appear to be induced in part by FSH itself as, in the present study, FSH decreased $\mathrm{FSHr}$ mRNA but increased P450scc mRNA and stimulated progesterone production. $\mathrm{FSH}$, even at the lowest dose (4 $\mathrm{ng} \mathrm{ml}^{-1}$ ) tested in this study (near the physiological (plasma) concentration; Krishnan et al., 1993), stimulated a maximum increase in P450scc mRNA abundance and
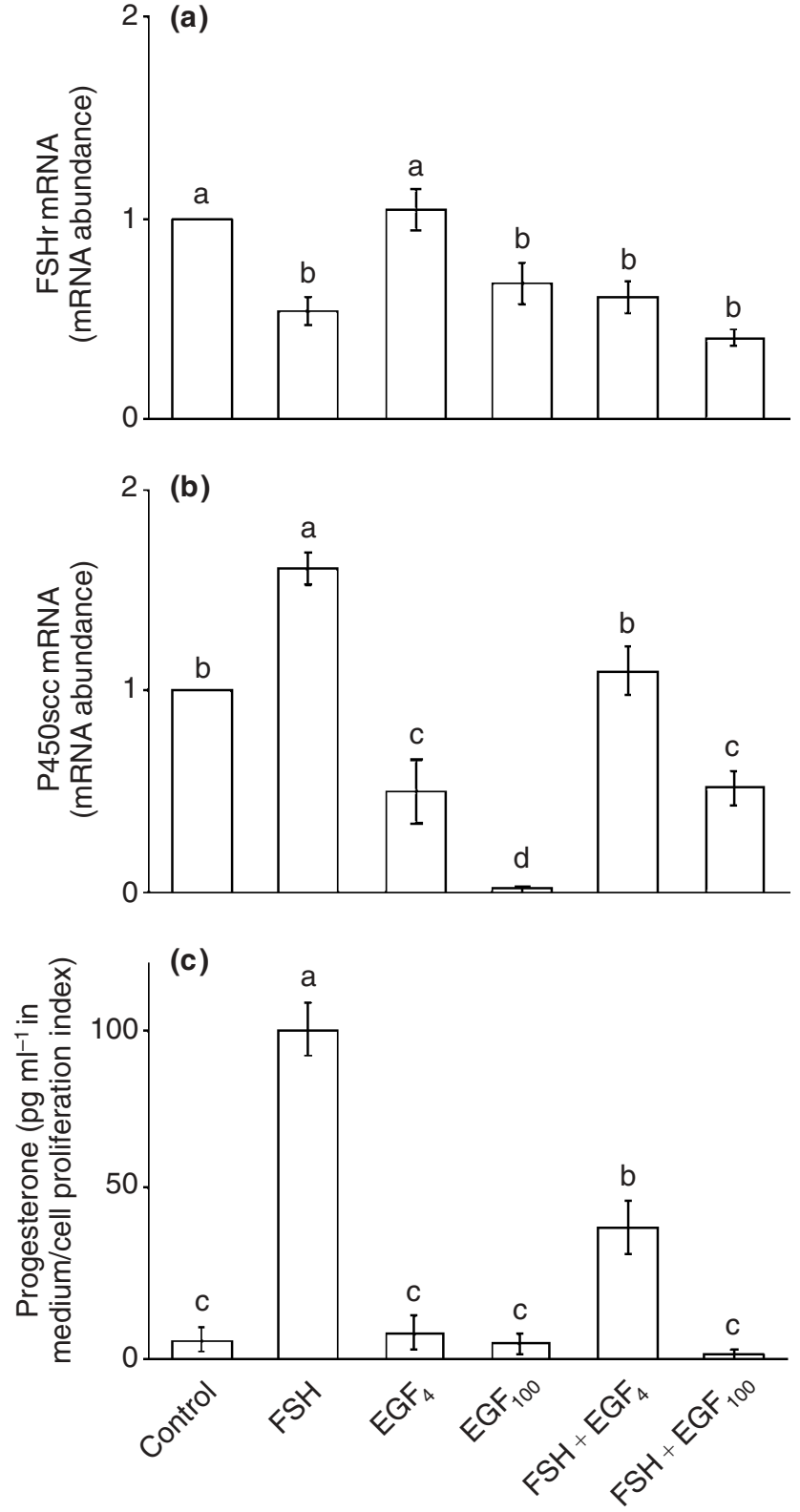

Fig. 3. Abundance of (a) $\mathrm{FSH}$ receptor (FSHr) and (b) $\mathrm{P} 450$ side-chain cleavage (P450scc) mRNA, and (c) production of progesterone in granulosa cells of small yellow follicles (SYF) in response to combinations of pig $\mathrm{FSH}$ and human recombinant epidermal growth factor in chicken ovaries. Granulosa cells from SYF were cultured for $18 \mathrm{~h}$ with different doses of the hormones. Transcript abundance was determined by semi-quantitative PCR. Data for FSHr and P450scc mRNA are expressed as mean \pm SEM $(n=4)$, relative to dose $0 \mathrm{ng} \mathrm{ml}^{-1}$, with dose $0=1$. Data for progesterone production are expressed as mean $\pm \operatorname{SEM}(n=4) \mathrm{pg} \mathrm{ml}^{-1}$ in culture medium relative to cell proliferation index. Different subscripts indicate significant differences $(P<0.05)$. EGF: epidermal growth factor; $\mathrm{EGF}_{4}$ : $4 \mathrm{ng} \mathrm{EGF} \mathrm{ml}{ }^{-1} ; \mathrm{EGF}_{100}: 100 \mathrm{ng} \mathrm{EGF} \mathrm{ml}{ }^{-1}$.

a significant increase in progesterone production. These effects of FSH imply that FSH is one of the factors responsible fo $r$ selection of follicles into the hierarchy, 
because only granulosa cells of hierarchical follicles secrete progesterone. However, the abundance of FSHr mRNA was not different in F6 and SYF. It is possible that the decrease of FSHr mRNA abundance observed in the present in vitro experiments in response to FSH and EGF correspond to those observed in vivo at later stages of development, for example, in the F3-F1 follicles, where FSHr mRNA and FSHr binding are at their lowest (Ritzhaupt and Bahr, 1987).

EGF is a paracrine factor produced by the germinal disc and granulosa cells. EGF promotes cell proliferation at the expense of cell differentiation, and stimulates cell proliferation and suppresses progesterone secretion by granulosa cells of preovulatory follicles (Volentine et al., 1998; Yao and Bahr, 2001a). In the current study, EGF prevented differentiation of granulosa cells of SYF by completely suppressing the expression of P450scc mRNA and progesterone secretion. When used in combination with FSH, EGF reduced (at $4 \mathrm{ng} \mathrm{ml}^{-1}$ ) or completely suppressed (at $100 \mathrm{ng} \mathrm{ml}^{-1}$ ) FSH-stimulated P450scc mRNA and progesterone production. These data strongly indicate that EGF is at least one of the factors that prevents the induction of steroidogenesis in granulosa cells of SYF. Individual differences in concentrations of EGF in the germinal disc and granulosa cells or responsiveness to EGF or FSH among SYF may determine which follicle escapes the inhibitory effect of EGF and initiates production of progesterone by granulosa cells.

EGFr mRNA abundance was not affected by FSH or EGF. In other species, EGFr has been shown to be upregulated by gonadotrophins (Feng et al., 1987; Fujinaga et al., 1994). Expression of EGFr by granulosa cells of preovulatory follicles is not influenced by EGF or LH in chickens (Yao and Bahr, 2001b). Unpublished data from the present authors' laboratory indicate that the abundance of EGFr mRNA does not change with follicular maturation. However, immunocytochemical studies indicate that the granulosa cells of small, unselected follicles have a slightly stronger staining for EGFr protein than the preovulatory follicles (Onagbesan et al., 1994). Furthermore, the proliferative response of granulosa cells to EGF is greater in smaller follicles compared with preovulatory follicles (Peddie et al., 1994). These data indicate that the ultimate balance between FSH and EGF in inducing or preventing steroidogenesis in SYF (and possibly selection) may reside at the receptor protein level. In addition, a change in the FSH-stimulated cAMP and EGF-stimulated tyrosine kinase signalling pathways may also be responsible for the initiation of steroidogenesis. However, the cross-talk between signalling pathways in granulosa cells is not yet fully understood (Haynes-Johnson et al., 1999; Johnson and Bridgham, 2001).

In summary, the results of the present study strengthen the hypothesis that $\mathrm{FSH}$ promotes initiation of steroidogenesis in granulosa cells of SYF, whereas EGF opposes this effect. Follicular selection is associated with an increase in P450scc mRNA in granulosa cells. Whereas FSH induces the onset of steroidogenesis in granulosa cells of SYF by increasing P450scc mRNA and progesterone production, EGF negates these effects. Whether a SYF is selected or remains in the pool of undifferentiated follicles may depend, at least in part, on individual differences among the SYF in responsiveness to FSH and EGF.

The authors wish to thank J. Van Cleeff for her critical reading of the manuscript and A. F. Parlow for the gift of pig FSH. This study was supported by Cooperative State Research, Education and Extension Service, United States Department of Agriculture; project number ILLU-35-0311.

\section{References}

Bahr JM and Calvo FO (1984) A correlation between adenylyl cyclase and responsiveness to gonadotropins during follicular maturation in the domestic hen. In Reproductive Biology of Poultry pp 75-88 Eds FJ Cunningham, PA Lake and D Hewitt. British Poultry Science, Harlow

Bahr JM, Wang SC, Dial OK and Calvo FO (1983) Steroid concentration in isolated theca and granulosa layers of preovulatory follicles during the ovulatory cycle of the domestic hen Biology of Reproduction 29 326-334

Calvo FO and Bahr JM (1983) Adenylyl cyclase of the small preovulatory follicles of the domestic hen: responsiveness to follicle stimulating hormone and luteinizing hormone Biology of Reproduction 29 542-547

Calvo FO, Wang SC and Bahr JM (1981) LH-stimulable adenylyl cyclase activity during the ovulatory cycle in granulosa cells of the three largest follicles and the postovulatory follicle of the domestic hen (Gallus domesticus) Biology of Reproduction 25 805-812

Feng P, Knecht M and Catt K (1987) Hormonal control of epidermal growth factor receptors by gonadotropins during granulosa cell differentiation Endocrinology 120 1121-1126

Fujinaga H, Yamamoto M, Shikone T and Nakano R (1994) FSH and LH upregulate epidermal growth factor receptors in rat granulosa cells Journal of Endocrinology 140 171-177

Gilbert AB, Evans AJ, Perry MM and Davidson MH (1977) A method for separating the granulosa cells, the basal lamina and the theca of the preovulatory ovarian follicle of the domestic fowl (Gallus domesticus) Journal of Reproduction and Fertility 50 179-181

Hammond RW, Burke WH and Hertelendy F (1981) Influence of follicular maturation on progesterone release in chicken granulosa cells in response to turkey and ovine gonadotropins Biology of Reproduction 24 1048-1055

Haynes-Johnson D, Lai MT, Campen C and Palmer S (1999) Diverse effects of tyrosine kinase inhibitors on follicle stimulating hormonestimulated estradiol and progesterone production from rat granulosa cells in serum-containing medium and serum-free medium containing epidermal growth factor Biology of Reproduction 61 147-153

Hernandez AG and Bahr JM (2002) Culture of chicken granulosa cells from small yellow follicles: a suitable culture system Journal of Poultry Science 39 14-21

Johnson AL and Bridgham JT (2001) Regulation of steroidogenic acute regulatory protein and regulatory protein and luteininzing hormone receptor messenger ribonucleic acid in hen granulosa cells Endocrinology 142 3116-3124

Johnson AL, Bridgham JT and Wagner B (1996) Characterization of a chicken luteinizing hormone receptor (cLH-R) complementary deoxyribonucleic acid, and expression of cLH-R messenger ribonucleic acid in the ovary Biology of Reproduction 55 304-309

Knecht M and Catt KJ (1983) Modulation of cAMP-mediated differentiation in ovarian granulosa cells by epidermal growth factor and plateletderived growth factor Journal of Biological Chemistry 258 2789-2794 
Krishnan KA, Proudman DJ and Bahr JM (1993) Development of an homologous radioimmunoassay for chicken follicle stimulating hormone and measurement of plasma FSH during the ovulatory cycle Comparative Biochemistry and Physiology 105A 729-734

Lax I, Johnson A, Howk R, Sap J, Bellot F, Winkler M, Ullich A, Vennstrom B, Schlessinger J and Givol D (1988) Chicken epidermal growth factor (EGF) receptor: cDNA cloning, expression in mouse cells and differential binding of EGF and transforming growth factor alpha Molecular and Cellular Biology 8 1970-1978

Li Z and Johnson AL (1993) Regulation of P450 cholesterol side-chain cleavage messenger ribonucleic acid expression and progesterone production in hen granulosa cells Biology of Reproduction $49463-$ 469

Nitta H, Osawa Y and Bahr JM (1991) Immunolocalization of steroidogenic cells in small follicles of the chicken ovary: anatomical arrangement and location of steroidogenic cells change during follicular development Domestic Animal Endocrinology 8 587-594

Onagbesan OM, Gullick W, Woolveridge I and Peddie MJ (1994) Immunohistochemical localization of epidermal growth factor receptors, epidermal growth factor-like and transforming growth factor- $\alpha$-like peptides in chicken ovarian follicles Journal of Reproduction and Fertility 102 147-153

Palmer SS and Bahr JM (1992) Follicle stimulating hormone increases serum oestradiol-17 $\beta$, number of growing follicles and yolk deposition in aging hens (Gallus domesticus) with decreased egg production British Poultry Science 33 403-414

Peddie M, Onagbesan M and Woolveridge I (1993) The role of epidermal growth factor and other factors in the paracrine and autocrine control of ovarian follicular development in the domestic hen. In Avian Endocrinology pp 321-330 Ed. PJ Sharp. Journal of Endocrinology Ltd, Bristol

Peddie MJ, Onagbesan OM and Williams J (1994) Chicken granulosa cell proliferation and progesterone production in culture: effects of EGF and theca secretions General and Comparative Endocrinology 94 341-356

Porunelloor AM, Kagawa N, Bhasker CR and Waterman MR (1990) Deduced amino acid sequence of heme binding region of chicken cholesterol side chain cleavage cytochrome P450 Protein Sequences and Data Analysis 3 323-325

Ritzhaupt LK and Bahr JM (1987) A decrease in FSH receptors of granulosa cells during follicular maturation in the domestic hen Journal of Endocrinology 115 303-310

Tilly JL, Kowalski KI and Johnson AL (1991) Stage of ovarian follicular development associated with the initiation of steroidogenic competence in avian granulosa cells Biology of Reproduction 44 305-314

Volentine KK, Yao HHC and Bahr JM (1998) Epidermal growth factor in the germinal disc: potential role of the oocyte in follicular development in the chicken Biology of Reproduction 59 522-526

Yao HHC and Bahr JM (2001a) Germinal disc-derived epidermal growth factor: a paracrine factor to stimulate proliferation of granulosa cells Biology of Reproduction 64 390-395

Yao HHC and Bahr JM (2001b) Chicken granulosa cells show differential expression of epidermal growth factor (EFG) and luteinizing hormone (LH) receptor messenger RNA and differential responsiveness to EGF and LH dependent upon location of granulosa cells to the germinal disc Biology of Reproduction 64 1790-1796

You S, Bridgham JT, Foster DN and Johnson AL (1996) Characterization of the chicken follicle stimulating hormone receptor (cFSH-R) complementary deoxyribonucleic acid, and expression of cFSH-R messenger ribonucleic acid in the ovary Biology of Reproduction 551055 1062

Zhang C, Shimada K, Saito N and Kansaku N (1997) Expression of messenger ribonucleic acid of luteinizing hormone and follicle stimulating hormone receptors in granulosa and theca layers of chicken preovulatory follicles General and Comparative Endocrinology 105402 409

Received 8 November 2002.

First decision 20 December 2002.

Revised manuscript received 16 January 2003.

Accepted 16 January 2003. 